\title{
Malignant dysgerminomatous germ cell tumor of the ovary
}

INSERM

\section{Source}

INSERM. (1999). Orphanet: an online rare disease and orphan drug data base. Malignant dysgerminomatous germ cell tumor of the ovary. ORPHA:99912

Malignant dysgerminomatous germ cell tumor of ovary is the most common form of malignant germ cell tumor of ovary (see this term), arising from germ cells in the ovary, usually presenting during adolescence with pelvic mass, fever, vaginal bleeding, and acute abdomen and is characterized by bilaterality (around $10 \%$ of cases), association with dysgenetic gonads ( 5 to $10 \%$ of cases), elevated serum lactate dehydrogenase (LDH) and human chorionic gonadotrophin (hCG) (in the presence of syncitiotrophoblasts). Malignant dysgerminomatous germ cell tumor of ovary responds well to chemotherapy, potentially sparing patients from infertility and early mortality. 